\title{
PENGARUH MUTASI KERJA DAN PROMOSI JABATAN TERHADAP MOTIVASI KERJA APARATUR SIPIL NEGARA (ASN) PADA SEKRETARIAT DAERAH KABUPATEN KERINCI
}

\author{
Ade Nurma Jaya Putra S.Sos., M.A.P \\ STIA Nusantara Sakti Sungai Penuh \\ Email: ade.nurmajaya@gmail.com
}

\begin{abstract}
ABSRACT
This study aims to determine the effect of mutation and promotion of position on work motivation. The number of samples determined was 68 respondents using the Quantitative method. As an independent variable, namely work mutation and promotion while the dependent variable is work motivation. The analysis used is multiple linear analysis includes, coefficient of determination and hypothesis testing. The results of the analysis using multiple linear can be seen that the mutation variable affects motivation by 1,227 (122\%) and Job Promotion affects Work Motivation by 0.067 (6.7\%) both of these variables affect the performance and the results of the analysis using the coefficient of determination is known that 0.962 (96.2\%) Variations in work motivation can be explained by the independent variables examined in this study and 3.8\% are explained by other factors beyond this discussion. And the results of hypothesis testing both partially and simultaneously that the independent variable on the dependent variable there is a significant influence using the t-test and f-test
\end{abstract}

Keywords: Mutation, Promotion, Work Motivation of State Civil Apparatus (ASN).

\section{ABSTRAK}

Penelitian ini bertujuan untuk mengetahui Pengaruh mutasi dan promosi jabatan terhadap motivasi kerja. Jumlah sampel yang ditetapkan sebanyak 68 responden dengan menggunakan metode Kuantitatif. Sebagai variabel independen, yaitu mutasi kerja dan Promosi Jabatan sedangkan variabel dependennya adalah Motivasi kerja. Analisis yang digunakan adalah analisis linier berganda meliputi, Koifisien determinasi dan pengujian hipotesis. Hasil analisis menggunakan Liner berganda dapat diketahui bahwa variabel mutasi mempengaruhi motivasi sebesar 1,227 (122\%) dan Promosi Jabatan mempengaruhi Motivasi Kerja sebesar 0.067 (6.7\%) hal tersebut kedua variable berpengaruh terhadap kinerja dan hasil analisis menggunakan koefisien determinasi diketahui bahwa $0.962(96.2 \%)$ variasi dari motivasi kerja dapat dijelaskan oleh variabel bebas yang diteliti dalam penelitian ini dan 3,8\% dijelaskan oleh faktor-faktor lain di luar pembahasan ini. Dan hasil uji hipotesis baik secera parsial maupun secara simultan bahwa variable independen terhadap variable dependen terdapat pengaruh yang singnifikan dengan menggunakan Uji-t dan Uji-f

Kata kunci: Mutasi, Promosi, Motivasi Kerja Aparatur Sipil Negara (ASN). 


\section{PENDAHULUAN}

\section{1 latar Belakang}

Dalam perkembangan pada era reformasi yang serba kompetitif ini, baik itu organisasi pemerintahan maupun organisasi privat akan selalu dihadapkan pada permasalahan salah satunya adalah sumber daya manusia (SDM) atau tenaga kerja, sumber daya manusia tidak hanya unik dan berharga, tetapi sumber daya organisasi yang paling penting. Tampaknya logis bahwa suatu organisasi akan mengeluarkan banyak usaha untuk memperoleh dan memanfaatkan sepenuhnya sumber daya tersebut. Karna sumber daya manusia penentu terwujudnya tujuan orgnasisai tersebut meskipun sarana dan prasarana memadai. Oleh sebab itu agar pelaksanaan tugas organisasi dapat berjalan efektif, efisien dan optimal dituntut mengelola sumber daya manusia yang terencana dan berkelanjutan. Salah satu hal yang dapat dilakukan adalah mempertahankan motivasi pegawai itu sendiri.

Didalam organisasi harus memastikan bahwa karyawan termotivasi, motivasi yang tinggi berasal dari praktik manajemen yang efektif. Motivasi (motivation) sebagai proses individual internal yang memberi energi, mengarahkan, dan memelihara perilaku (Pride Hughes Kapoor, 356: 2014). Ini adalah "kekuatan" pribadi yang menyebabkan untuk bertindak dengan cara tertentu. Motivasi sering, diartikan dengan istilah dorongan, yang berarti tenaga yang menggerakkan jiwa dan jasmani untuk berbuat, sehingga motif merupakan "driving force" seseorang, untuk bertingkah laku dalam mencapai tujuan yang telah ditetapkan. dalam meningkatkan motivasi kerja seseorang tentu tidaklah mudah. Tentu ada factor-factor yang dapat mempengaruhi salah satunya terkait dengan mutasi pegawai. 
Mutasi atau pemindahan merupakan kegiatan dari pimpinan organisasi untuk memindahkan karyawan dari suatu pekerjaan ke pekerjaan yang lain yang dianggap setingkat atau sejajar. Mutasi adalah merupakan suatu kegiatan rutin dari suatu organisasi untuk dapat melaksanakan prinsip " the right man in the right place" atau "orang tepat pada tempat yang tepat. selain dari pada mutasi promosi juga merupakan salah satu factor yang dapat mempengaruhi motivasi kerja.

Promosi salah satu dorongan seseorang bekerja pada suatu organisasi atau perusahaan adalah adanya kesempatan untuk maju. Sudah menjadi sifat dasar manusia pada umumnya untuk menjadi lebih baik, lebih maju dari posisi yang dipunya pada saat ini. Kesempatan untuk maju di dalam organisasi sering disebut sebagai promosi (naik pangkat). Suatu promosi berarti pemindahan dari suatu jabatan ke jabatan lain yang mempunyai status dan tanggung jawab yang lebih tinggi (Priyono Marnis 191:2018).

Sekretariat Daerah Kabupaten Kerinci sebagai suatu lembaga yang memiliki tugas membantu Bupati dalam melaksanakan tugasnya sebagai penyelenggaraan pemerintahan, baik itu dalam hal tugas administrasi, organisasi dan tata laksana serta memberikan pelayanan administrasif kepada seluruh perangkat daerah Kabupaten Kerinci lainnya, yang dibentuk berdasarkan Perda Kabupaten Kerinci Nomor 13 Tahun 2011, tentang Organisasi Sekretariat Daerah dan Sekretariat Dewan Perwaklilan Rakyat Daerah Kabupaten Kerinci Jo Peraturan Bupati Kerinci Nomor 10 Tahun 2011 tanggal 13 Juni 2011 tentang Uraian Tugas Pokok, Fungsi dan Tata Kerja Sekretariat Daerah Kabupaten Kerinci, Sekretariat Daerah Kabuapaten Kerinci, tentu membutuhkan sumber daya manusia yang berkualitas. Untuk mewujudkan 
visi Misi Sekretariat Daerah Kabupaten Kerinci memotivasi pegawai tentu menjadi salah satu aspek penting karena merupakan fakrot penting untuk meningkatkan kinerja.

Berdasarkan Penelitian awal yang peneliti laksanakan di sekretariat daerah Kabupaten Kerinci terkait dengan motivasi kerja promosi dan mutasi pegawai terlihat masih rendah hal ini terlihat dari beberapa fenomena sebagai berikut:

1. Masih banyak pegawai yang duduk dikantin padahal jam kantor/dinas sudah mulai.

2. Masih banyak pegawai yang diangkat untuk meduduki jabatan tertentu belum sesuai dengan aturan.

3. Masih banyak pegawai yang mempunyai pengalaman kerja dan prestasi kerja yang baik serta masa kerja yang lama belum menduduki jabatan yang sesuai.

4. Kurangnya pengahargaan yang diberikan kepada Aparatur Sipil Negara yang berprestasi sehingga menurunkan tingkat motivasi bekerja karena dirasa kurang dihiperhatikan pekerjaanya.

5. Masih rendahnya kedisiplinan pegawai dalam mengikuti jam dinas atau jam kantor. Contohnya : terdapat beberapa pegawai yang tidak masuk kerja tanpa memberikan alasan yang jelas baik kepada atasan maupun kepada rekan kerja serta sering terlambat dan pulang terlebih dahulu.

Berdasarkan fenomena yang penulis uraikan tentu terkait dengan factor-faktor yang mempengaruhi motivasi kerja maka sebab itu penulis tertarik untuk meneliti dengan judul Pengaruh Mutasi dan Promosi Jabatan Terhadap Motivasi Kerja Aparatur Sipil Negara pada Sekretariat Daerah Kabupaten Kerinci.

\subsection{Rumusan Masalah}


Berdasarkan uraian latar belakang diatas, maka dapat dirumuskan masalah yang akan diteliti dalam penelitian ini adalah sebagai berikut:

1. Apakah terdapat Pengaruh baik secara Persial dan Simultan antara Mutasi dan Promosi Jabatan tehadap Motivasi Kerja Aparatur Sipil Negara pada Sekretariat Daerah Kabupaten Kerinci.?

2. Seberapa besar Pengaruh baik secara persial dan simultan antara Mutasi dan Promosi Jabatan tehadap Motivasi Kerja Aparatur Sipil Negara pada Sekretariat Daerah Kabupaten Kerinci.?

3. Variabel manakah yang paling dominan mempengaruhi Motivasi Kerja Aparatur Sipil Negara pada Sekretariat Daerah Kabupaten Kerinci.?

\subsection{Tujuan Penelitian}

Adapun tujuan dari penelitian ini adalah untuk mengetahui hal-hal sebagai berikut:

1. Pengaruh baik secara Persial dan Simultan antara Mutasi dan Promosi Jabatan tehadap Motivasi Kerja Aparatur Sipil Negara pada Sekretariat Daerah Kabupaten Kerinci?

2. besar Pengaruh baik secara persial dan simultan antara Mutasi dan Promosi Jabatan tehadap Motivasi Kerja Aparatur Sipil Negara pada Sekretariat Daerah Kabupaten Kerinci?

3. Variabel manakah yang paling dominan mempengaruhi Motivasi Kerja Aparatur Sipil Negara pada Sekretariat Daerah Kabupaten Kerinci?

\subsection{Manfaat Penelitian}

Adapun manfaat penelitian yang ingin di capai dalam penelitian ini adalah Sebagai berikut :

1. Manfaat Praktis 
Penelitian ini diharapkan menjadi sumbangan pemikiran bagi dinas/instansi dalam mengembangkan sumber daya manusia

2. Manfaat Akademis

Dengan penulisan Proposal ini diharapkan dapat memberikan manfaat bagi penulis dalam mengembangkan wawasan berfikir dan menambah pembendaharaan pengetahuan, khususnya mengenai konsep dan teori- teori yang berhubungan dengan penelitian ini.

\subsection{Tinjauan Pustaka}

\section{Pengertian Mutasi}

Menurut Sondang P. Siagian (2015:171) Mutasi adalah penempatan seseorang pada tugas baru dengan tanggung jawab, hierarki jabatan dan penghasilan yang relatif sama dengan statusnya yang lama. Dalam hal demikian seorang pegawai ditempatkan pada satuan kerja baru yang lain dari satuan kerja di mana seseorang selama ini berkarya.

Mutasi/transfer terjadi kalau seorang karyawan dipindahkan dari satu bidang tugas ke bidang tugas lainnya yang tingkatannya hampir sama baik tingkat gaji, tanggung jawab, maupun tingkat strukturalnya. Mutasi bahkan mungkin lebih bermanfaat bagi para karyawan, karena pengalaman kerja mereka akan bertambah dan mempunyai keahlian baru dan dalam perspektif yang berbeda mereka juga akan menjadi karyawan yang lebih baik sehingga menjadi calon kuat untuk dipromosikan di masa mendatang (Veithzal Rivai, 2009:156). Sedangkan Menurut Kadarisman (2012:68) Mutasi adalah kegiatan ketenagakerjaan yang berhuubungan dengan proses pemindahan fungsi, tanggung jawab, dan status ketenagakerjaan tenaga kerja ke situasi tertentu dengan tujuan agar tenaga kerja yang bersangkutan 
memperoleh kepuasan kerja yang mendalam dan dapat memberikan prestasi kerja yang maksimal mungkin kepada organisasi

\section{Promosi}

Menurut Sondang P. Siagian (2015:169) Promosi ialah apabila seorang pegawai dipindahkan dari satu pekerjaan ke pekerjaan lain yang tanggung jawabnya lebih besar, tingkatannya dalam hierarki jabatan yang lebih tinggi dan penghasilannya pun lebih besar pula. Setiap pegawai mendambakan promosi karena dipandang sebagai penghargaan atas keberhasilan seseorang menunjukkan prestasi kerja yang tinggi dalam menunaikan kewajibannya.

Sedangkan menurut Veithzal Rivai (2009:155) Promosi terjadi apabila seorang karyawan dipindahkan dari satu pekerjaan ke pekerjaan lain yang lebih tinggi dalam pembayaran, tanggung jawab dan atau level. Hal ini juga sama dengan pendapat Priyono Marnis (2008:191) Promosi adalah perpindahan dari suatu jabatan ke jabtan lain yang mempu

\section{Motivasi Kerja}

Handoko (2000:127) menjalankan motif atau dalam bahasa asing di sebut motive adalah sesuatu seperti kebuthan atau keingan yang mendorong atau mempengaruhi seseorang untuk melakukan gerak. Sedangkan Moh. As'ad (2009:45) menjabarkan bahwa motif seringkali di artikan dengan istilah dragon atau tenaga tersebut merupakan gerak jiwa dan jasmani untuk berbuat. Sehingga motif tersebut merupakan suatu driving force yang menggerakan manusia untuk bertingkah laku, dan di dalam perbuatanya itu mempunyai tujuan ketentuan.

Hampir sama dengan pendapat dua ahli tersebut, pengertian motivasi menurut Rivai (2006:837) adalah serangkai sikap dan nilai-nilai yang mempengaruhai individu untuk 
mencapai hal yang spesifik sesuai dengan tujuan individu. Sikap dan nilai tersebut merupakan suatu yang invisible yang memberikan kekuatan untuk mendorong individu bertingkah laku dalam mencapaitujuan. Singkatnya, kadarisman (2012: 275) menggerakan motivasi adalah sebagai pendorong manusia untuk bertindak dan berbuat.

Selanjutnya, Kadarisman (2012: 278) menyatakan bahwa motivasi kerja adalah sesuatu yang menimbulkan semangat atau dorongan dalam diri seseorang untuk mau bekerja dengan giat dan baik. Kuat atau lemahnya motivasi kerja ditentukan oleh terpenuhinya harapanharapan, keinginan atau kebutuhannya.Hal ini sama seperti yang diungkapkan oleh Moh. As'ad (2009:50) motivasi kerja sebagai suatu yang menumbulkan dorongan atau semngat kerja atau pendorong semangat kerja.

\subsection{Kerangka Pemikiran}

Kerangka pemikiran ini dimaksudkan sebagai konsep untuk menjelaskan hubungan variabel yang akan diteliti berdasarkan perumusan masalah, adapun kerangka pemikiran dalam penelitian ini adalah terdiri dari dua variabel bebas (X1) dan (X2) dan satu variabel terikat (Y), Yaitu :

\section{Variabel X1 (Mutasi Kerja)}

Menurut Kadarisman (2012:68) Mutasi adalah kegiatan ketenagakerjaan yang berhuubungan dengan proses pemindahan fungsi, tanggung jawab, dan status ketenagakerjaan tenaga kerja ke situasi tertentu dengan tujuan agar tenaga kerja yang bersangkutan memperoleh kepuasan kerja yang mendalam dan dapat memberikan prestasi kerja yang maksimal mungkin kepada organisasi. Adapun indikator mutasi Kerja menurut kadarisman (2012: 130) adalah: 
1) Frekuensi Mutasi Frekuensi mutasi adalah tingkat keseringan pelaksanaan mutasi dalam organisasi.

2) Alasan Mutasi

3) Ketetapan dalam melaksanakan mutasi yang disesuaikan dengan: Kemampuan kerja pegawai, Tingkat Pendidikan, Lamanya masa menjabat, Tanggung jawab atau beban kerja, Kesenangan atau keinginan pegawai, Kebijaksanaan atau peraturan yang berlaku, serta Kesesuaian antara jabatan yang lama dan jabatan yang baru.

\section{Variabel X2 (Promosi)}

Menurut Sondang P. Siagian (2015:169) Promosi ialah apabila seorang pegawai dipindahkan dari satu pekerjaan ke pekerjaan lain yang tanggung jawabnya lebih besar, tingkatannya dalam hierarki jabatan yang lebih tinggi dan penghasilannya pun lebih besar pula. Adapun indikator promosi jabatan menurut Malayu S.P. Hasibuan (2013:111) Yaitu:

1) Kejujuran yang artinya karyawan harus jujur terutama pada dirinya sendiri, bawahannya, perjanjian-perjanjian dalam menjalankan atau mengelola jabatan tersebut, harus sesuai kata dengan perbuatannya. Dia tidak menyelewengkan jabatannya untuk kepentingan pribadinya.

2) Disiplin yang artinya Karyawan harus disiplin pada dirinya, tugas-tugasnya, serta menaati peraturan-peraturan yang berlaku baik tertulis maupun kebiasaan. Disiplin karyawan sangat penting karena hanya dengan kedisiplinan memungkinkan perusahaan dapat mencapai hasil yang optimal.

3) Prestasi Kerja yang artinya Karyawan itu mampu mencapai hasil kerja yang dapat dipertanggung jawabkan kualitas maupun kuantitas dan bekerja secara efektif dan 
efisien. Hal ini menunjukkan bahwa karyawan dapat memanfaatkan waktu dan mempergunakan alat-alat dengan baik.

4) Kerja Sama yang artinya Karyawan dapat bekerja sama secara harmonis dengan sesama karyawan baik horizontal maupun vertikal dalam mencapai sasaran perusahaan, Dengan demikian akan tercipta suasana hubungan kerja yang baik di antara semua karyawan.

5) Kecakapan yang artinya Karyawan itu cakap, kreatif, dan inovatif dalam menyelesaikan tugas- tugas pada jabatan tersebut dengan baik. Dia bisa bekerja secara mandiri dalam menyelesaikan pekerjaannya dengan baik, tanpa mendapat bimbingan yang terusmenerus dari atasannya.

6) Loyalitas yang artinya Karyawan harus loyalitas dalam membela perusahaan atau korps dari tindakan yang merugikan perusahaan atau kopsnya. Ini menunjukkan bahwa dia ikut berpartisipasi aktif terhadap perusahaan atau korpsnya.

\section{Variabel Y (Motivasi Kerja)}

Handoko (2000:127) menjalankan motif atau dalam bahasa asing di sebut motive adalah sesuatu seperti kebuthan atau keingan yang mendorong atau mempengaruhi seseorang untuk melakukan gerak. Adapun indikator Motivasi Kerja menurut Hasibuan ( 2000:246 ) adalah:

1) Upah yang adil dan layak

Upah yang adil dan layak merupakan penghasilan yang cukup untuk memenuhi kebutuhan dasar karyawan dan keluarganya. Ini berarti bahwa pekerjaan mendapat uang yang cukup untuk membayar makanan, perumahan, pakaian dan layanan yang sangat diperlukan lainnya seperti transportasi, kesehatan dan pendidikan anak-anak.

2) Kesempatan untuk maju 
Kesempatan untuk maju di dalam suatu organisasi disebut dengan promosi (kenaikan tingkat jabatan). Promosi adalah kesempatan dimana seseorang dapat memperbaiki posisi jabatannya. Promosi berarti perpindahan dari suatu jabatan ke jabatan yang lain, yang mempunyai status dan tanggung jawab yang lebih tinggi.

3) Pengakuan sebagai individu

Pengakuan sebagai individu merupakan pengakuan seseorang terhadap suatu kelompok, atau seberapa besarnya kebanggaan seseorang sebagai anggota kelompok, dalam dirinya masih timbul tuntutan untuk diakui sebagai individu. Dengan mengakui karyawan sebagai individu, kita memenuhi berbagai kebutuhan pisikologisnya.

4) Keamanan bekerja

Keamanan bekerja adalah unsur-unsur penunjang yang mendukung terciptanya suasana kerja yang aman, baik berupa material maupun non material. Unsur-unsur penunjang keamanan yang bersifat material dan non material diantaranya pengunaan baju kerja, rambu-rambu isyarat bahaya dan sebagainya.

5) Pengakuan atas Prestasi

Pengakuan terhadap prestasi merupakan pengakuan yang diberikan berdasarkan keahlian dalam menyelesaikan tugas yang telah diberikan serta meraih suatu prestasi yang baik selama bekerja.

Gambar 1.1 kerangka pemikiran

Mutasi Kerja $\left(X_{1}\right)$

1. Frekuensi Mutasi

2. Alasan Mutasi

3. Ketepatan Mutasi

Motivasi Kerja (Y)

1. Upah yang adil dan layak

2. Kesempatan Untuk maju

3. Pengakuan sebagai individu

4. Keamanan Bekerja 
Sumber: kadarisman (2012: 130)
Promosi Jabatan $\left(\mathrm{X}_{2}\right)$
1. Kejujuran
2. Kedisplinan
3. Prestasi Kerja
4. Kerja Sama
5. Kecakapan
6. Loyalitas

Sumber: Hasibuan (2013:111)

\subsection{Hipotesis}

Pengertian hipotesis menurut Sugiyono (2009: 64) adalah jawaban sementara terhadap rumusan penelitian di mana rumusan masalah penelitian telah dinyatakan dalam bentuk kalimat pernyataan. Dikatakan sementara, karena jawaban yang diberikan baru didasarkan pada teori yang relefan, belum didasarkan pada fakta-fakta empiris yang diperoleh melalui pengumpulan data. Jadi hipotesis juga dapat dinyatakan sebagai jawaban teoritis terhadap rumusan masalah penelitian, belum jawaban yang empirik.

Berdasarkan pengkajian dari uraian di atas sehingga hipotesis ini dapat dikemukakan sebagai berikut:

Ho $: r=0$ Di duga tidak terdapat pengaruh yang signifikan antara mutasi kerja dan promosi jabatan terhadap motivasi kerja Aparatur Sipil Negara (ASN) di Sekretariat Daerah Kabupaten Kerinci. 
Ha $: r \neq 0$ Di duga Terdapat pengaruh yang signifikan antara mutasi kerja dan promosi jabatan terhadap motivasi kerja Aparatur Sipil Negara (ASN) di Sekretariat Daerah Kabupaten Kerinci

\section{METODE PENELITIAN}

\subsection{Metode Penelitian}

Adapun Metode Penelitian yang digunakan dalam penelitian ini adalah sebagai berikut

\subsubsection{Pendekatan Penelitian}

Pendekatan penelitian yang digunakan dalam penelitian ini adalah Kuantitatif. Sugiono (2011: 37) kuantitatif adalah data yang berwujud angka-angka yang diperoleh sebagai hasil pengukuran atau penjumlahan. Data-data kuantitatif inilah yang kemudian yang kemudian bisa diolah dengan tekhnik statistik. Teknik analisis yang digunakan untuk menganalisis dengan melakukan perhitungan pengaruh mutasi dan promosi terhadap Motivasi kerja Aparatur Sipil Negara (ASN) di Sekretariat Daerah Kabupaten Kerinci.

\subsubsection{Populasi}

Menurut Riduwan (2009: 6) populasi merupakan objek atau subjek yang berada pada suatu wilayah dan memenuhi syarat-syarat tertentu berkaitan dengan masalah penelitian. Sugiyono (2009: 80), populasi adalah wilayah generalisasi yang terdiri atas objek atau subjek yang mempunyai kualitas dan karakteristik tertentu yang ditetapkan oleh peneliti untuk

dipelajari dan kemudian ditarik kesimpulannya. Berdasarkan kualitas dan ciri tersebut, populasi dapat dipahami sebagai sekelompok individu atau objek pengamatan yang minimal memiliki satu persamaan karakteristik. 
Populasi dalam penelitian ini adalah seluruh Aparatur Sipil Negara (ASN) pada Sekretariat Daerah Kabupaten Kerinci yang berjumlah 123 orang.

\subsubsection{Sampel}

Untuk memperoleh sampel pada penelitian ini, peneliti menggunakan rumus Slovin (Husein Umar, 2014:78), yaitu sebagai berikut:

$$
\mathrm{n}=\frac{N}{1+N\left(e^{2}\right)}
$$

Keterangan:

$\mathrm{n} \quad=$ Jumlah sampel

$\mathrm{N} \quad=$ Jumlah populasi

e =presentase kelonggaran karena kesalahan pengambilan sampel yang masih ditolelir (ketidaktelitian).

Dalam penelitian ini $\mathrm{N}=123$ dan $\mathrm{e}=0,08$, maka:

$$
\begin{aligned}
& \mathrm{n}=\frac{123}{1+123(0.08)^{2}} \\
& \mathrm{n}=\frac{123}{1+0,7872} \\
& \mathrm{n}=\frac{123}{1,7872} \\
& \mathrm{n}=68,22 \rightarrow 68
\end{aligned}
$$

Berdasarkan hitungan di atas didapatkan jumlah sampel sebesar 68 dari 123 jumlah pegawai Sekretariat Daerah Kabupaten Kerinci. Untuk penentuan sampel dalam penelitian ini menggunakan teknik propotional stratified random sampling yaitu teknik pengambilan 
sampel yang diambil dari masing-masing sub populasi yang diambil secara acak berdasarkan proporsi jumlah pangkat golongan pegawai yang ada pada setiap subpopulasi.

Table Distribusi Sampel Penelitian

\begin{tabular}{|c|c|c|c|c|}
\hline Pangkat & $\begin{array}{c}\text { Jumlah } \\
\text { Populasi }\end{array}$ & \multicolumn{2}{|c|}{ Proporsi Sampel } & Jumlah Sampel \\
\hline Golongan IV & 30 & $30 / 123 \times 68=$ & 16,58 & 16 \\
\hline Golongan III & 61 & $61 / 123 \times 68=$ & 33,72 & 33 \\
\hline Golongan II & 32 & $32 / 123 \times 68=$ & 17,69 & 17 \\
\hline Jumlah & $\mathbf{1 2 3}$ & $\mathbf{1 2 3}$ & $\mathbf{6 7 . 9 9}$ & $\mathbf{6 8}$ \\
\hline
\end{tabular}

\subsubsection{Teknik Pengumpulan Data}

Teknik pengumpulan data adalah cara-cara yang digunakan untuk mengumpulkan data dan keterangan-keterangan lainnya dalam penelitian yang dilakukan. Teknik pengumpulan data primer yang digunakan adalah field research, yang dilakukan dengan cara:

\section{Observasi}

Observasi merupakan cara atau teknik untuk memperoleh data dengan mengadakan pengamatan langsung dilokasi penelitian.

\section{Kuesioner}

Kuesioner adalah teknik pengumpulan data dengan menyebarkan suatu daftar pertanyaan yang diajukan secara tertulis kepada responden, dalam penelitian ini penulis, menyebarkan kuesioner pada masyarakat pengguna jasa pelayanan pada Kantor Pertanahan Kabupaten Kerinci.

\subsubsection{Interprestasi data}

\section{Skala Likert}

Sugiono (2009: 93) Skala likert digunakan untuk mengukur sikap, pendapat, dan persepsi seseorang atau sekelompok orang tentang fenomena sosial. Dalam penelitian, 
fenomena sosial ini telah ditetapkan secara spesifik oleh peneliti, yang selanjutnya disebut sebagai variabel penelitian.

Setiap jawaban dari responden diklasifikasikan sebagai berikut:

$\begin{array}{lll}\text { SS }=\text { Sangat Setuju } & \text { diberi skor } & 5 \\ \text { ST }=\text { Setuju } & \text { diberi skor } & 4 \\ \text { KS = Kurang Setuju } & \text { diberi Skor } & 3 \\ \text { TS = Tidak Setuju } & \text { diberi skor } & 2 \\ \text { STS = Sangat Tidak Setuju } & \text { diberi skor } & 1\end{array}$

Sumber: Imam Ghozali (2013:47)

\section{Analisis Regresi Linear Sederhana}

Analisis Regresi linear berganda adalah suatu alat analisis peramalan nilai pengaruh satu variabel bebas terhadap variabel terikat untuk membuktikan ada atau tidaknya hubungan fungsi atau hubungan kausal antara variabel bebas dengan variabel terikat (Riduwan, 2005 : 155). Menurut Ghozali (2006:82) dalam analisis regresi selain mengukur kekuatan hubungan antara dua variabel dependen dengan variabel independen. Artinya model regresi dapat digunakan untuk menentukan variabel yang mempengaruhi dan variabel yang dipengaruhi. Sesuai dengan desain penelitian ini, dengan instrument angket skala likert maka data penelitian yang dikumpulkan berskala interval, maka untuk model penelitian ini teknik analisis yang layak digunakan adalah teknik regresi, khususnya regresi linear berganda. Persamaan regresi berganda dirumuskan sebagai berikut :

$\mathrm{Y}=\mathrm{a}+\mathrm{b} 1 \mathrm{X} 1+\mathrm{b} 2 \mathrm{X} 2+\mathrm{e}$

Keterangan : 


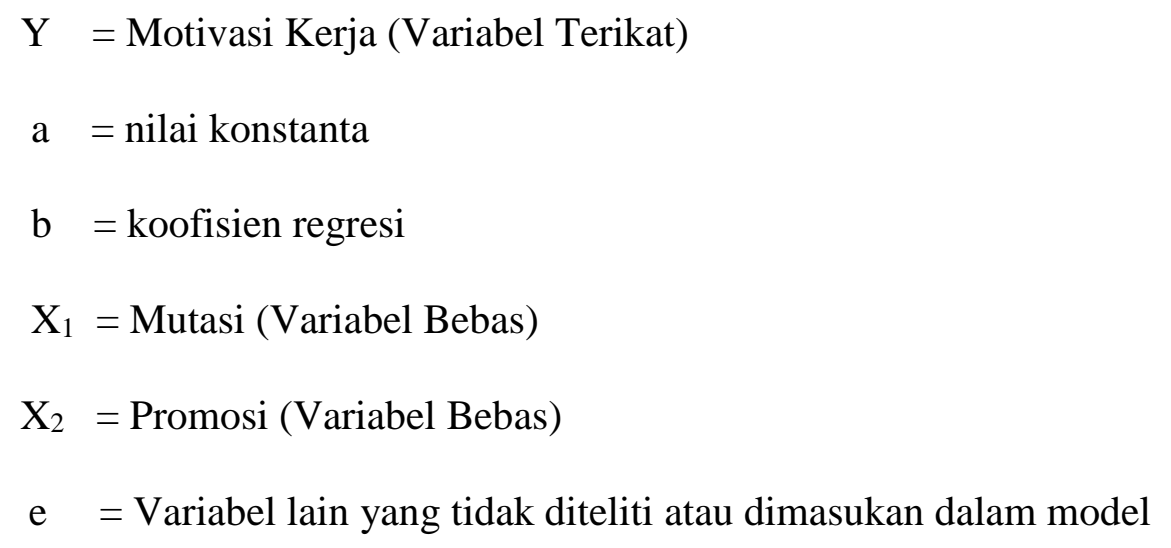

\section{Koofesien determinasi}

Koefisien determinasi merupakan kuadrat dari koefisien korelasi. Analisis ini digunakan untuk mengetahui seberapa besar pengaruh variabel independen $(\mathrm{X})$ terhadap variabel dependen (Y).

$K D=r_{x y^{2}} x 100 \%$

Dimana:

$\mathrm{KD}=$ Koefisien Determinasi

$\mathrm{r}_{x y}{ }^{2}=$ Koefisien kuadrat korelasi ganda

\section{Uji t}

Uji t adalah bagian dari uji statistik yang merupakan yang digunakan untuk membuktikan pengaruh variabel $X$ terhadap variabel $Y$, maka dihitung dengan rumus Sugiono (2009: 184) sebagai Berikut:

$t=\frac{r \sqrt{n-2}}{\sqrt{1-r^{2}}}$

Dimana: 


$$
\begin{array}{ll}
\mathrm{t}_{\text {hitung }} & =\text { Nilai } \\
\mathrm{r} & =\text { Nilai Koefisien Korelasi } \\
\mathrm{n} & =\text { Jumlah Sampel }
\end{array}
$$

\section{HASIL DAN PEMBAHASAN}

\section{Analisis Regresi Linear Beganda}

Pada penelitian ini teknik analisis data yang digunakan adalah regresi berganda. Teknik analisis ini digunakan untuk mengetahui besarnya pengaruh Mutasi dan Promsi Jabatan terhadap Motivasi Kerja Aparatur Sipil Negara (ASN) Pada Sekretariat Daerah Kabupaten

\begin{tabular}{|c|c|c|c|c|c|c|}
\hline \multicolumn{7}{|c|}{ Coefficients $^{a}$} \\
\hline \multirow{2}{*}{\multicolumn{2}{|c|}{ Model }} & \multicolumn{2}{|c|}{ Unstandardized Coefficients } & \multirow{2}{*}{$\begin{array}{c}\begin{array}{c}\text { Standardized } \\
\text { Coefficients }\end{array} \\
\text { Beta }\end{array}$} & \multirow[b]{2}{*}{$\mathrm{t}$} & \multirow[b]{2}{*}{ Sig. } \\
\hline & & B & Std. Error & & & \\
\hline \multirow[t]{3}{*}{1} & (Constant) & .775 & 1.208 & & .642 & .523 \\
\hline & MUTASI & 1.225 & .034 & .940 & 3.957 & .000 \\
\hline & PROMOSI & .067 & .018 & .095 & 3.636 & .001 \\
\hline
\end{tabular}
Kerinci, dengan pengolahan SPSS versi 17.0 maka didapat hasil regresi sebagai berikut:

Tabel : Hasil Analisis Regresi

a. Dependent Variable: MOTIVASI KERJA

Dalam penelitian ini, hasil regresi menggunakan standardized coefficients. Persamaan linier dari hasil regresi yang didapat adalah sebagai berikut :

$\mathrm{Y}=0.775+1.225 \mathrm{X}_{1}+0.067 \mathrm{X}_{2}+\mathrm{e}$

Keterangan :

1. Nilai $\alpha($ Constan $)=0,775$ 
Artinya apabila dianggap tidak ada mutasi dan Promosi Jabata maka Motivasi Kerja Aparatur Sipil Negara (ASN) sebesar 0.775

2. Nilai $b_{1}=1.225$

artinya terjadi peningkatan apabila Mutasi dinaikan 1\% maka Motivasi kerja akan mengalami peningkatan sebesar 1.225

3. Nilai $b_{2}=0.067$

artinya terjadi peningkatan apabila Promosi dinaikan 1\% maka Motivasi Kerja akan mengalami peningkatan sebesar 0.067

Berdasarkan tabel diatas, diketahui Faktor Mutasi (X1) merupakan faktor dominan yang mempengaruhi Motivasi Kerja Aparatur Sipil Negara (ASN) pada Sekretariat Daerah Kabupaten kerinci sebesar 1.225( $122 \%)$

\section{Koifesien Determinasi $\left(\mathbf{R}^{2}\right)$}

Koifesien determinasi $\left(\mathrm{R}^{2}\right)$ pada intinya mengukur seberapa jauh kamampuan model menerangkan variasi variabel dependennya. Nilai koefisen determinasi yang mendekati satu berarti variabel -variabel independenya menjelaskan hampir semua informasi yang dibutuhkan untuk mempredeksi variabel dependen (Ghozali.2009). hasil perhitungan determinasi penelitian ini dapat dilihat pada tabel berikut :

\section{Tabel : Koifesien Determinasi}

\begin{tabular}{|l|r|r|r|r|}
\hline \multicolumn{1}{|c|}{ Model Summary } \\
\hline Model & $\mathrm{R}$ & R Square & Adjusted R Square & Std. Error of the Estimate \\
\hline 1 & $.981^{\mathrm{a}}$ & .962 & .961 & .734 \\
\hline
\end{tabular}

a. Predictors: (Constant), PROMOSI, MUTASI 
Nilai adjusted $r$ square sebesar 0.962 yang artinya Mutasi dan Promosi Jabatan mampu mempengaruhi Motivasi Kerja apartur sipil Negara (ASN) sekretariat daerah Kabupaten Kerinci sebesar $96.2 \%$, sementara sisanya sebesar 3.8\% di pengaruhi faktor variabel lain.

\section{Uji -t ( Uji Partial)}

Uji - $\mathrm{t}$ ini digunakan untuk membuktikan adanya pengaruh yang signifikan antara Mutasi dan Promosi Jabatan terhadap Motivasi Kerja secara parsial. Ketentuan t tabel (Sugioyono 2007 :368) :

$\alpha=0,05$ (satu sisi) $; \mathrm{n}-2=68-2=66$, maka $\mathrm{t}$ tabel $=1.668$

Ketentuan penerimaan hipotesis yaitu :

Ha ditolak bila sig. $>0,05$ atau $t$ hitung $<\mathrm{t}$ tabel

Ha diterima bila sig. $\leq 0,05$ atau $t$ hitung $>\mathrm{t}$ tabel

Berdasarkan hasil pengolahan dengan program SPSS maka di dapat hasil uji - $t$, yang hasilnya dirangkum pada tabel berikut ini

Tabel : Hasil Uji - t

\begin{tabular}{|c|c|c|c|c|c|c|}
\hline \multicolumn{7}{|c|}{ Coefficients $^{a}$} \\
\hline \multirow{2}{*}{\multicolumn{2}{|c|}{ Model }} & \multicolumn{2}{|c|}{ Unstandardized Coefficients } & \multirow{2}{*}{$\begin{array}{c}\text { Standardized Coefficients } \\
\text { Beta }\end{array}$} & \multirow[b]{2}{*}{$\mathrm{t}$} & \multirow[b]{2}{*}{ Sig. } \\
\hline & & B & Std. Error & & & \\
\hline 1 & (Constant) & .775 & 1.208 & & .642 & .523 \\
\hline & MUTASI & 1.225 & .034 & .940 & 3.957 & .000 \\
\hline & PROMOSI & .067 & .018 & .095 & 3.636 & .001 \\
\hline
\end{tabular}

a. Dependent Variable: MOTIVASI KERJA

\section{Pengaruh mutasi terhadap Motivasi Kerja}

Berdasarkan hasil pengolahan data pada tabel diatas diperoleh nilai $t_{\text {hitung }}>t_{\text {tabel }}$ yaitu 3.957>1.668 dengan koefesien regresi 1.225, maka Ho di tolak dan Ha diterima, hal ini berarti 
bahwa secara persial variable Mutasi mempunyai pengaruh signifikan terhadap Motivasi Kerja aparatur sipil Negara (ASN) pada Sekretariat Daerah Kabupaten Kerinci.

\section{Pengaruh Promosi Jabatan terhadap Motivasi Kerja}

Berdasarkan hasil pengolahan data pada tabel diatas diperoleh nilai $t_{\text {hitung }}>t_{\text {tabel }}$ yaitu 3.636>1.668 dengan koefesien regresi 0.067, maka Ho di tolak dan Ha diterima, hal ini berarti bahwa secara persial variabel Promosi Jabatan mempunyai pengaruh dan signifikan terhadap Motivasi Kerja Aparatur Sipil Negara (ASN) pada Sekretriat Daerah Kabupaten Kerinci.

\section{Uji -F (Uji Simultan)}

Uji - F ini digunakan untuk membuktikan apakah semua variabel bebas yaitu Mutasi dan Promosi Jabatan berpengaruh secara bersama-sama terhadap variabel terikat yaitu Motivasi Kerja. Berdasarkan hasil pengolahan dengan program SPSS versi 17.0 maka di dapat hasil uji $-\mathrm{F}$, yang hasilnya dapat dilihat sebagai berikut :

\section{Tabel : Uji- F (Secara Simultan)}

\begin{tabular}{|l|r|r|r|r|r|}
\hline Model & Sum of Squares & df & Mean Square & F & Sig. \\
\hline 1 Regression & 895.615 & 2 & 447.807 & 831.225 & $.000^{\mathrm{a}}$ \\
Residual & 35.018 & 65 & .539 & & \\
Total & 930.632 & 67 & & & \\
\hline
\end{tabular}

a. Predictors: (Constant), PROMOSI, MUTASI

b. Dependent Variable: MOTIVASI KERJA

Dari tabel 3.4 terlihat bahwa nilai signifikan yang didapat sebesar $0,000(<0,05)$, berdasarkan hasil uji $\mathrm{F}$ tersebut, maka variabel bebas secara bersama-sama memberikan pengaruh yang signifikan terhadap variabel terikat, jadi dapat diartikan bahwa Mutasi dan 
Promosi Jabatan secara bersama-sama berpengaruh signifikan terhadap Motivasi Kerja Aparatur Sipil Negara (ASN) pada Sekretariat Daerah Kabupaten Kerinci.

\section{SIMPULAN}

Berdasarkan hasil pengolahan data sebelumnya dengan menggunakan program SPSS 17.0 untuk menganalisis pengaruh mutasi dan promosi Jabatan terhadap Motivasi Kerja aparatur sipil Negara (ASN) Pada sekretariat daerah kabupaten Kerinci, didapatkan hasil sebagai berikut

1. beradasarkan uji $\mathrm{t}$, dari hasil regresi nilai thitung masing-masing variable adalah Mutasi $=$ 3.957 dan Promosi Jabatan $=3.636$ jika dibandikan dengan signifikan yang telah ditentukan yaitu $\alpha=0,05\left(t_{\text {tabel }}=1.668\right)$ maka thitung $>t_{\text {tabel, }}$ dengan demikian mutasi dan promosi berpengaruh signifikan terhadap motivasi kerja aparatur sipil Negara (ASN) pada Sekretariat daerah kabupaten kerinci.

2. beradasarkan uji F, dari hasil regresi terlihat bahwa nilai signifikan yang didapat sebesar 0,000 $(<0,05)$, berdasarkan hasil uji $\mathrm{F}$ tersebut, maka variabel bebas secara bersama-sama memberikan pengaruh yang signifikan terhadap variabel terikat, jadi dapat diartikan bahwa Mutasi dan Promosi Jabatan secara bersama-sama berpengaruh signifikan terhadap Motivasi Kerja Aparatur Sipil Negara (ASN) pada Sekretariat Daerah Kabupaten Kerinci

3. Dari olah data diperoleh nilai adjusted $r$ square sebesar 0.962 Ini berarti mutasi dan promosi jabatan berpengaruh terhadap motivasi kerja aparatur sipil Negara (ASN) Pada sekretariat daerah kabupaten Kerinci sebesar 96,2\%.

4. dilihat dari olah hasil regresi liner berganda dengan menggunakan program SPPS 17.0 didapatkan varibel Mutasi (X1) merupakan variabel yang paling dominan mempengaruhi 
Motivasi Kerja Aparatur Sipil Negara (ASN) pada Sekretariat daerah kabupaten kerinci, dengan nilai koefisien sebesar $122 \%$.

\section{UCAPAN TERIMA KASIH}

Terima Kasih Kepada LPPM STIA Nusantara sakti Sungai Penuh yang telah member kesempatan untuk publish jurnal OJS Jurnal Administrasi Nusantara (JAN), serta semua pihak yang tidak bisa disebutkan satu persatu dalam jurnal ini.

\section{DAFTAR PUSTAKA}

Ghozali. 2001. Analisis Multivariate dengan Program SPSS. Badan Penerbit Universitas Diponegoro. Semarang.

Handoko Hani. 2000. Manajemen Personalia dan Sumber Daya Manusia. Yogyakarta: BPFE Yogyakarta

Hasibuan, Drs, H.Malayu.S.P. 2013. Manajemen Sumber Daya Manusia (Edisi Revisi). Jakarta: Bumi Aksara.

Kadarisman, 2012. Manajemen Pengembangan Sumber Daya Manusia, Jakarta: Rajawali Pers

Kapoor, Pride Hughes.2014. Pengantar Bisnis edisi II, Jakarta: Salemba Empat.

Marnis, Priyono. 2018. Manajemen Sumber Daya Manusia, Surabaya: Zifatama Fublisher

Moh. As'ad. 2009. Seri Ilmu sumber daya manusia, Psikologi Industri, Edisi IV, Yogyakarta: Liberty

Siagian, MPA, Prof.Dr.Sondang. 2015. Manajemen Sumber Daya Manusia. Jakarta: Bumi Aksara Siagian, MPA, Prof.Dr.Sondang.2012.Teori Pengembangan Organisasi. Jakarta: Bumi Aksara

Sugiyono, 2009, Metode Penelitian Pendidikan (Pendekatan Kuantitatif, Kualitatif dan R \& , Alfabeta :Bandung.

Sugiono.2011. Metode Penelitian Pendidikan Pendekatan Kuantitatif, Kualitatif,dan R\&D. Bandung: Alfabeta

Vertizal Rivai. 2009. Manajemen Sumber Daya Manusia Untuk Perusahaan Teori ke Praktek. Jakarta: Raja Grafindo Persada

Riduwan. 2003. Dasar-dasar Statistika. Bandung: Alfabeta 
(A) Jurnal Administrasi Nusantara (JAN)

Volume 3 No. 1 - Juni 2020 